\title{
A REVIEW: THE EFFECTIVENESS OF EDIBLE COATING INCORPORATED WITH RED MACROALGAE (Kappaphycus alvarezii) EXTRACT ON THE POST HARVEST QUALITY OF FRUITS
}

\author{
NUR SYAMIMI HAZIQAH ACHONG@ASMAT AND FAUZIAH TUFAIL AHMAD*
}

Faculty of Fisheries and Food Science, Universiti Malaysia Terengganu, 21030 Kuala Nerus, Terengganu, Malaysia.

*Corresponding author: fauziah.tufail@umt.edu.my

http://doi.org/10.46754/umtjur.2021.10.017

\begin{abstract}
Fruits and vegetables are the main fresh produce that receive high demand among consumers because of the nutritional properties to boost the human health. However, not all fruits and vegetables are durable due to the ongoing release of ethylene even when harvested. Damaged produce will not be accepted by the customer and will cause post-harvest losses. It was estimated that about $30 \%$ of fruits and vegetables are damaged or affected by microorganisms, insects, pre- and post-harvest conditions during transportation and improper storage conditions. Edible coating is an effective approach for fruit preservation. It provides good barrier properties towards carbon dioxide, oxygen, and moisture vapor and at the same time beneficial for the environment and human health. The aim of this review is to investigate the potential of red macroalgae (Kappaphycus alvarezii) as an edible fruit coating. This edible red macroalgae abundant in Sabah is widespread around the world due to their carrageenan properties. Carrageenan is normally used as the main edible coating material due to its thickening stability and natural antioxidant. The carrageenan film from these algae is able to replace synthetic packaging and is more environmentally friendly. The abundant source of this algae in Sabah will ensure sustainability and cost effectiveness besides increasing the socio-economy of the local community. Red macroalgae has potential to be used as a bio preservative in fresh produce as it shows better quality characteristics in physicochemical properties of fruits such as weight loss, colour and firmness.
\end{abstract}

Keywords: Edible coating, red macroalgae, post-harvest quality, fruits.

\section{Introduction}

Fruits and vegetables contain a lot of beneficial nutrients for human health as they contain $80 \%$ to $90 \%$ water content by weight. Some of the fruits and vegetables are very sensitive after being harvested and must be consumed or processed in a very short time to avoid the loss of nutritional content in the fresh produce. Major losses in quality and quantity of fresh fruits occur between harvest and minimally processed to be consumed by the consumers. Fruits and vegetables still remain physiologically active and continue their metabolic process which can easily be exposed by improper handling, inadequate storage temperature and transportation ( $\mathrm{Li}$ et al., 2017). After the fruit is harvested, the metabolism process will occur with the change of gaseous balance between the usage of oxygen and the production of carbon dioxide in the fruit. The loss of reserved substrates in the fresh fruits and vegetables will fasten the process of natural senescence as the source of energy to prolong the shelf life of the fresh produce is decreased (Mahajan et al., 2014). This senescence phase will reduce the quality of the fresh produce in terms of nutritional content, flavor attributes, physical damage, unattractive color that will be rejected by consumers and cause post-harvest losses (Chakraborty et al., 2018). Thus, edible coating is highly needed as it has a function as a protective natural barrier that uses natural ingredients which can be eaten together with the fruits as well as minimizing the physiological disorder (Galgano, 2015; Raghav et al., 2016; Hassan et al., 2018). Edible coating such as red macroalgae (Kappaphycus alverazii) is one of methods which can be used as a coating to the fruits to extend the shelf life to meet the 
postharvest quality required by consumers. Edible coating is an alternative method to extend the post-harvest life of fresh produce and minimally processed fruits and vegetables (Ochoa-Reyes et al., 2019). Generally, the properties of edible coatings consist of hydrophobic group, such as hydrocolloids or hydrophilic group, lipid-based or waxes, protein-based or combination of both groups to improve function of edible coating (Pascall $\&$ Lin, 2013). Red macroalgae is one of the sources rich in carrageenan properties such as sulphated polysaccharide extracted from the cell wall of different red macroalgae from the family of Rhodophyceae (Karbowiak et al., 2007). Moreover, it is a good source of compounds with potential application in food industry because it is known for their high polysaccharide, protein, mineral and vitamin contents, low lipid content and for the presence of antioxidants as one of bioactive compounds (Haddar et al., 2012). This treatment can maintain or slower the deterioration process of colour oxidation, maturity stage and firmness as it acts as barrier that is able to decrease moisture, weight loss and prevent microorganism penetration (Hamzah et al., 2013; Augusto et al., 2016; de Oliviera et al., 2018; Ramani \& Aswini, 2020). The purpose of this study is to review the efficiency of red macroalgae extract as edible coating as protective layer on the post-harvest quality of fruits.

\section{Red Macroalgae (Kappaphycus alvarezii)}

Red macroalgae, Kappaphycuss alvarezii is one of the marine algae that is important and highly demanded for its cell wall polysaccharide and carrageenan, thus making it the most important carrageenophyte in the world (Bindu \& Levine, 2011). Red macroalgae is from Primoplantae clade and is included in a group of non-vascular plants consisting of 6100 species of wide variety of size and shape (Cian et al., 2015). It has many abnormal morphology and mode of reproduction (Usov, 1992). Red macroalgae is wild aquatic plant that is abundant on the coast especially in coral reefs and protected beaches (Figure 1). Seaweed is one type of algae and can be recognized by different pigment colours such as red, green and brown (Gupta \& AbuGhannam, 2011). Seaweed comes from the large plant size called macroalgae which is classified into three major groups based on pigmentation: red seaweeds (Rhodophyceae), green seaweeds (Chlorophyceae) and brown seaweeds (Phaephyceae) (Samarakoon \& Jeon, 2012). Moreover, various products have been produced, both food and non-food (Ghadiryanfar et al., 2016).

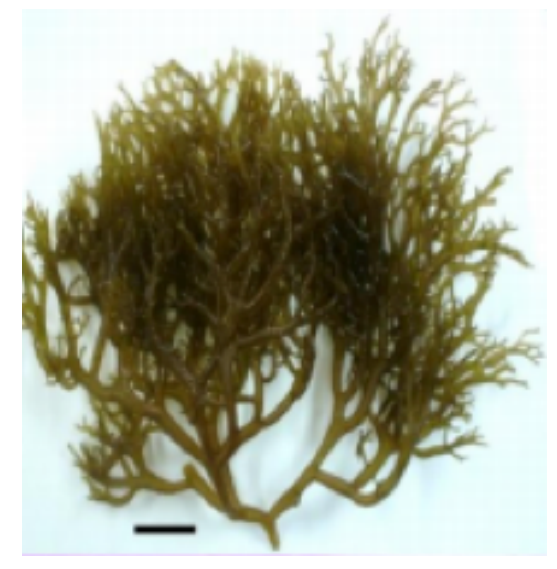

Figure 1: The red macroalgae variety of $K$. alvarezii 
Red macroalgae are one of the largest groups of algae for consumption worldwide, containing a good source of $\mathrm{K}$-carrageenan which is a major component of dietary fibre (Jumaidin et al., 2017). Carrageenan also plays a big role for gelling, stabilizing properties and thickening agents for pharmaceutical industries and food (Lahaye \& Kaeffer, 1997; Mustapha et al., 2011; Ramani \& Aswini, 2020). Hence, red macroalgae play a large role of functional properties such as thermal stability, gelling ability and potential against health risk because they consist of bountiful polysaccharides as a biodegrade polymer (Thakur et al., 2017). Red macroalgae are sustainable natural resources that have higher industrial potential and not fully utilized. The largest production of seaweed is in Sabah, Malaysia with the total production of $15,000 \mathrm{MT}$ in 2010 and it is expected to increase over times (Tan et al., 2011), (Mustapha et al., 2011; Ramani \& Aswini, 2020).

\section{Processing of Red Macroalgae}

Red macroalgae are ready to be harvested within two months. There are some areas in certain villages in Semporna that have shorter cultivation period, between one to 1.5 months. Red macroalgae need to be dried to increase the shelf life before further use. There are two types of drying methods viz. drying on the platform and hanging method. Basically, the drying process usually takes time from three to five days and up to seven days depending on the weather condition (Sade \& Ariff, 2006).

The optimum moisture content in dried red macroalgae ranges from $25 \%$ to $30 \%$ (Goh $\&$ Lee, 2010). Due to the slow drying rate of hanging method, this method is less popular to be used among the local farmers. Transparent plastic is usually used to cover the seaweed throughout the drying process (Sade \& Ariff, 2006).

\section{Properties of Red Macroalgae}

In general, red macroalgae are photosynthetic containing chlorophyll a and $\mathrm{d}$, inadequacy of flagella, and consist of carotenoids and phycobiliproteins (allophycocyanin, phycoerythrin and phycocyanin) as accessory pigments (Denis et al., 2009). Basically, Rhodophyta which has presence of accessory pigments can grow up at $200 \mathrm{~m}$ deep with the ability to survive at the great depth (Lee, 2008). Moreover, red macroalgae (i.e. Rhodopyta) have attracted food and pharmaceutical industry for the search of new natural nutrients and bioactive compounds (Ficko-Blean et al., 2017). On the other hand, among seaweeds, the red algae contain high amount of carbohydrate and minerals (Masarin et al., 2016). Moreover, specific functional properties have been attributed to rhodophyta proteins or peptides and polysaccharides because of their unique composition (Urbano \& Goni, 2002). These polysaccharides have chemical structures and physicochemical properties that differ substantially from those of land plants (Soares et al., 2016). Furthermore, red seaweeds have a unique polysaccharide composition and as there is no starch in chloroplasts, using floridean starch from cytoplasm as the food reserve (Yu et al., 2002).

Red macroalgae have been recognized as one of the marine microorganisms and $K$. alvarezii is the macroalgae that composed of $\mathrm{K}$-carrageenan. Due to the excellent properties of the carrageenan in red macroalgae (Table 1), it is suitable to be used in pharmaceuticals, food production and different application (Cian et al., 2015). The most common polysaccharide that can be split out from the red macroalgae are agar, carrageenan and alginate that had been utilized as coating materials (Gade et al., 2013). The carbohydrate polymers that can be extracted from the red macroalgae are alginates with the mannuronic-acid and guluronic-acid that are composed of polymers from the red macroalgae (Jard et al., 2013). Secondly, agar that contain the D-galactose and anhydro-L-galactose containing polymers that can be isolated from the red macroalgae (Yun et al., 2015). Thirdly, carrageenan that comes together with the pectin is the main natural gelling polysaccharide that can be extracted from the red macroalgae not including starch which receive a high demand between consumers as high-value food ingredient (Larotonda, 2007). 
Table 1: Characteristics of carrageenan (Source: Tobacman, 2001)

\begin{tabular}{ll}
\hline \multicolumn{1}{c}{ Source } & \multicolumn{1}{c}{$\begin{array}{c}\text { Mostly from the Red Macroalgae of Euchema sp. and } \\
\text { Kappaphycus alvarezii }\end{array}$} \\
\hline $\begin{array}{l}\text { Chemical } \\
\text { composition }\end{array}$ & $\begin{array}{l}\alpha \text {-D-1,3 and } \beta \text {-D-1,4 galactose residues that are sulfated up to } 40 \% \text { of } \\
\text { the total weight found in the hydrocolloid, low positive charge over } \\
\text { normal } \mathrm{pH} \text { range, related with magnesium, potassium, calcium and } \\
\text { sodium salts. } \\
\mathrm{k} \text { is soluble in a hot solution and the treatment of aqueous solution with } \\
\text { the potassium ion precipitates k-carrageenan. } \\
\text { K-carrageenan gel can be formed by the reaction of potassium chloride. } \\
\text { Solubility } \\
\text { Viscosity that ranges from } 5 \text { to } 800 \text { cps for } 1.5 \% \text { solution at } 75^{\circ} \mathrm{C} \text { and } \\
\text { the food grade of carrageenan based on viscosity are not less than } 5 \mathrm{cps}\end{array}$ \\
Viscosity & at $75^{\circ} \mathrm{C}$ for a $1.5 \%$ solution. \\
& Milk proteins help to combine $\chi$ and $\mathrm{k}$ carrageenan easily to enhance \\
the texture and solubility. The main role is as thickening agent, & stabilizer and emulsifier. \\
Properties & Hydrocolloids may affect the gel strength and cohesiveness. \\
& 0.005 to $2.0 \%$ by weight. \\
Synergic effects & Pharmaceuticals, cosmetics, skin preparations and processed meats. \\
Concentration in food products &
\end{tabular}

The Potential of Red Macroalgae (Kappaphycus alvarezii) Properties as Antimicrobial

Red macroalgae has carrageenan properties that function as antimicrobial agents (Ramani \& Aswini, 2020). Antimicrobial food packaging and based film is one of the alternatives for the concepts of active packaging (Quattara et al., 2000). The ideal of the biodegradable packaging and synthetic packaging consists of the film material which can prevent the spoilage of various microbial agents (Sung et al., 2013). The innovation of technology especially in edible coating has a great impact towards the postharvest quality of fresh produce (Dhall, 2013).

$\mathrm{K}$-carrageenan based film has been approved as one of the anti-microbial agents that contains ovotransferrin which can prolong the shelf life of the fresh chicken breast (Seol et al., 2009). The storage of fresh chicken breast can be prolonged at $5^{\circ} \mathrm{C}$ with slight antimicrobial activity especially Escherichia coli during seven days of storage. Besides, red macroalgae can inhibit Bacillus subtilis, Staphylococcus aureus, Lactobacillus acidophilius, E. coli, Pseudomonas aeruginosa, and Proteus mirabilis when treated as edible coating on the tomato with highest inhibition zone at $10000 \mu \mathrm{g} / \mathrm{mL}$ concentration (Ramani \& Aswini, 2020). This is because the application of carrageenan is beneficial towards fruit and meat due to the hydrocolloid property as functional food ingredient in edible coating formulation to improve the gelling effect, as micriobial inhibitor and prolong the shelf life (Masarin et al., 2016; Mohamed et al., 2020). Moreover, red macroalgae have ovotransferrin that can inhibit the microbial growth because it can isolate iron needed by microbes to survive (Pereira, 2017).

\section{Red Macroalgae Extraction}

Yield and gel strength of extracted carrageenan from macroalgae need to be analysed to determine the quality of carrageenan. The gel strength is important for stabilizing thickening agent in food products, cosmetics and pharmaceutical (Augusto et al., 2016). There are many ways to collect carrageenan extraction from the red macroalgae. The collected red 
macroalgae need to be sun-dried on the side for three days before being processed in the laboratory. Then, the dried algae were washed and penetrated to remove the visible foreign materials such as stones and sand. Salt content that will affect the final gelling property in the red macroalgae must be reduced by further washing with running deionized water for five minutes. Then, the excess moisture of pretreated red macroalgae was removed by drying in the oven at $60^{\circ} \mathrm{C}$ until constant weight was achieved. The dried pretreated algae were kept clean prior to analysis.

\section{Application of Red Macroalgae as Edible Coating}

Red macroalgae containing carrageenan with pectin is the main natural gelling polysaccharide (Rudolph, 1986). Carrageenan is a generic name that can be found from a family of water soluble, natural and sulphated galactans (Rudolph, 1986; Ren, 1997). Moreover, carrageenan can act as one important factor for food and pharmaceutical industries such as thickening, gelling and stabilizing agents (Tavassoli-Kafrani et al., 2016). All carrageenan properties are easily dissolved in water and hardly dissolved in organic solvents, fats and oils (Campo et al., 2009). The main cations obtained in carrageenan are potassium, calcium, magnesium, sodium and other ions but at lower frequency (OrtizTafoya et al., 2018). The gels formed from carrageenan have the viscosity solutions that can be determined from the equilibrium of cations in the water solution and the proportion of sulphate fractions (Siah \& Ishak, 2015).

Moreover, polysaccharide is a good barrier against gaseous such as oxygen, ethylene and carbon dioxide that can be found in one of the carrageenan properties split from the red macroalgae (Lacroix \& Tien, 2005). Furthermore, carrageenan application as a natural edible coating on papaya was able to lower oxygen permeability and able to reduce moisture loss from the thickening of carrageenan coating that soon will be dehydrated as a sacrificing agent (Hamzah et al., 2013). This can be proven by using carrageenan as an alternative coating on papaya which shows a positive effect from a combination of $0.78 \%(\mathrm{w} / \mathrm{v})$ carrageenan with $0.85 \%(\mathrm{w} / \mathrm{v})$ glycerol for a carrageenanbased coating. This treatment was effective as a physical barrier and reduced the weight loss and lowered the decay rate during post-harvest storage. Furthermore, red macroalgae are also used as edible film through casting technique. The ideal of innovated based film must be sealable, transparent and has good mechanical strength to withstand the pressure during handling throughout the post-harvest operation (Siah et al., 2015). Seaweed edible film had oxygen permeability rate of $18.54 \mathrm{~cm}^{3} \mu \mathrm{m} / \mathrm{m}^{2}$ day that shows excellent barrier properties than wheat gluten films. In another case study, the potential application of using seaweed extracts as post-harvest treatment, minimally processed in Fuji apples, has shown a positive result that this extraction is able to retard the enzyme activities and reduce browning index when compared with citric acid dipping treatment (Augusto et al., 2016).

\section{Effect of Red Macroalgae as Edible Coating on the Physico-chemical Properties of Fruit}

\section{Weight Loss}

Fruits and vegetables deteriorate easily as their metabolic process continues after harvest. The process will increase the weight loss due to loss of carbon reserves and transpiration (Mbele, 2017). Red macroalgae have potential as a good oxygen barrier that helps to prevent the weight loss of fruits (banana) contributed by the properties of polysaccharide (de Oliviera et al., 2018). Red macroalgae could retain the water in banana up to $95 \%$ at $25^{\circ} \mathrm{C} \pm 2{ }^{\circ} \mathrm{C}$ for 10 days (de Oliviera et al., 2018). Relative humidity also influences the oxygen barrier that will increase the oxygen permeability due to the swelling of hydrophilic films (Laufer et al., 2013). Other than that, comparing edible coating from two different species of macroalgae, K. alvarezii and Sargassum tenerrimum, shows that $K$. alvarezii was more effective in maintaining the weight loss of tomato by $6.33 \%$ than when 
treated with Sargassum tenerrimum by $16.16 \%$ and the control $19.64 \%$ after 28 days of storage at ambient temperature (Ramini and Aswini, 2020). K. alvarezii as edible coating is effective as a good barrier to the carbon dioxide and oxygen and helps to lower the moisture loss (Augusto et al., 2016).

\section{Colour}

The quality of the colour is the one that will affect consumers acceptance (Yousuf et al., 2018). The green colour is due to the presence of chlorophyll, which is magnesium-organic complex and this colour is easily lost due to the degradation of the chlorophyll structure (Nauyoma, 2015). The loss of green colour is one of the valuable guides to maturity. A study was conducted using Eksotika papaya that was coated with carrageenan and stored in $26^{\circ} \mathrm{C} \pm$ $2^{\circ} \mathrm{C}$ for five days at ambient condition. Both of the linear terms of carrageenan as edible coating on the surface of papaya show that significant difference $(\mathrm{p}<0.1)$ especially on the changes of the color components with the addition of glycerol give more positive effect on the appearance of the fruit. The values of $\mathrm{L}^{*}, \mathrm{a}^{*}$ and $\mathrm{b}^{*}$ are $31.5667,-68.7$ and -44.2333 respectively. Generally, the Eksotika papaya is able to maintain closer to the ground colour which is green, the increase of a value indicates the peel colour tends to the read and the increase of $b$ value tends to be the yellow color.

The application of red macroalgae extracts treatment for minimally processed of Fuji apples shows a good positive effect by an increase of a*, $\mathrm{b}^{*}$ and decrease of $\mathrm{L}^{*}$ value with the hue angle (Augusto et al., 2016). The enzymatic activity increases which leads to the tissues softening that promotes the enzyme substrate and causes the changes of browning for control. The minimally processed Fuji apples treated with red macroalgae extracts have an ideal protective effect that had lower significant changes $(p<$ $0.05)$ than the control.

\section{Firmness}

Postharvest quality of fruit can be observed through the changes in firmness caused by the ripening process (Galgano, 2015). Soft texture on the fruits is a sign of the reduction of firmness that occurred due to the breakdown of the polymeric substances. It usually happened during ripening process which affects the strength of the cell wall (Falguera et al., 2011). Basically, the loss of fruit firmness might be due to the low protection against transmission of water vapor that causes less cell tugor (Oms-Oliu et al., 2008). The application of carrageenan from the red macroalgae extraction as an edible coating on the fruits can reduce the oxygen permeability and reduce the respiration rate (Hamzah et al., 2013; Augusto et al., 2016).

Carrageenan was found to extend the shelf life of Eksotika papaya at ambient conditions (Hamzah et al., 2013). Next, seaweed extracts also play a big role on the post-harvest treatment for minimally processed Fuji apples (Augusto et al., 2016). The minimally processed was applied with seaweed extraction of $0.5 \%$ and the effect on the post-harvest quality was observed for 20 days of storage at $4{ }^{\circ} \mathrm{C} \pm 2{ }^{\circ} \mathrm{C}$ condition. The firmness results show that the changes associated with the change of temperature $(\mathrm{p}<$ 0.05 ) between the control and seaweed extracts of bifurcaria.

The application of carrageenan has the potential as an alternative coating as it reduces the fruit water loss (Pavlath \& Orths, 2009). The increase of carrageenan concentration may create a thick protective coating layer around the external fruit surface that prevents the moisture content and subsequently protect the fruit (Vargas et al., 2008).

\section{Conclusion}

Due to the high carrageenan content, red macroalgae have the potential to be used as edible coating to prolong the shelf life of fruit and vegetables. Application of this extract will be cost-effective source of natural antioxidants and can be used as an alternative method to 
synthetic coating of fruit. The application of this extract can also extend the ripening, reserve the nutritional content and good barrier properties against bacterial infection.

\section{Acknowledgements}

The authors would like to thank to the Faculty of Fisheries and Food Science, UMT for providing the financial support and facilities to carry out this project.

\section{References}

Augusto, A., Simões, T., Pedrosa, R., \& Silva, S. F. (2016). Evaluation of seaweed extracts functionality as post-harvest treatment for minimally processed Fuji apples. Innovative Food Science \& Emerging Technologies, 33, 589-595.

Bindu, M.S., \& Levine, I.A. (2011) The commercial red seaweed Kappaphycus alvarezii overview on farming and environment. Journal of Applied Phycology, 23(4), 789-796.

Campo, V.L., Kawano,D.F., da Silva Jr, D.B., \& Carvalho,I.(2009)Carrageenans: Biological properties, chemical modifications and structural analysis- A review. Carbohydrate polymers, 77(2), 167-180.

Chakraborty, I., Chattopadhyay, A. R. U. P., Chakraborty, I., \& Chattopadhyay, A. (2018). Pre-and post-harvest losses in vegetables. Advances in Postharvest Technologies of Vegetable Crops; CRC Press: Boca Raton, FL, USA, 25-87.

Cian, R. E., Drago, S. R., De Medina, F. S., \& Martínez-Augustin, O. (2015) Proteins and carbohydrates from red seaweeds: evidence for beneficial effects on gut function and microbiota. Marine Drugs, 13(8), 53585383.

Denis, C., Ledorze, C., Jaouen, P., \& Fleurence, J. (2009) Comparison of different procedures for the extraction and partial purification of R-phycoerythrin from the red macroalga
Grateloupia turuturu. Botanica Marina, 52(3), 278-281.

Gade, R., Tulasi, M. S., \& Bhai, V. A. (2013). Seaweeds: a novel biomaterial. International Journal of Pharmacy and Pharmaceutical Sciences, 5(2), 975-1491.

Galgano, F. (2015). Biodegradable packaging and edible coating for fresh-cut fruits and vegetables. Italian Journal of Food Science, 27(1), 1-20.

Falguera, V., Quintero, J. P., Jiménez, A., Muñoz, J. A., \& Ibarz, A. (2011) Edible films and coatings: Structures, active functions and trends in their use. Trends in Food Science \& Technology, 22(6), 292-303.

Ficko-Blean, E., Préchoux, A., Thomas, F., Rochat, T., Larocque, R., Zhu, Y., \& Viart, B. (2017) Carrageenan catabolism is encoded by a complex regulon in marine heterotrophic bacteria. Nature Communications, 8(1), 1-17.

Goh, C. S., \& Lee, K. T. (2010) A visionary and conceptual macroalgae-based thirdgeneration bioethanol (TGB) biorefinery in Sabah, Malaysia as an underlay for renewable and sustainable development. Renewable and Sustainable Energy Reviews, 14(2), 842-848.

Gupta, S., \& Abu-Ghannam, N. (2011). Bioactive potential and possible health effects of edible brown seaweeds. Trends in Food Science \& Technology, 22(6), 315326.

Ghadiryanfar, M., Rosentrater, K. A., Keyhani, A., \& Omid, M. (2016). A review of macroalgae production, with potential applications in biofuels and bioenergy. Renewable and Sustainable Energy Reviews, 54, 473-481.

Haddar, A., Sellimi, S., Ghammouchi, r., Alvarez, O.M., Nasri, M., \& Bougatef, A. (2012) Functional, antioxidant and filmforming properties of tuna-skin gelatin with brown algae extract. International Journal of Biological Macromolecules, 51 (4), 477 483. 
Hamzah, H. M., Osman, A., Tan, C. P., \& Ghazali, F. M. (2013) Carrageenan as an alternative coating for papaya (Carica papaya L. cv. Eksotika). Postharvest Biology and Technology, 75, 142-146.

Hassan, B., Chatha, S. A. S., Hussain, A. I., Zia, K. M., \& Akhtar, N. (2018) Recent advances on polysaccharides, lipids and protein based edible films and coatings: A review. International Journal of Biological Macromolecules, 109, 1095-1107.

Jard, G., Marfaing, H., Carrère, H., Delgenès, J. P., Steyer, J. P., \& Dumas, C. (2013) French Brittany macroalgae screening: composition and methane potential for potential alternative sources of energy and products. Bioresource Technology, 144, 492-498.

Jumaidin, R., Sapuan, S. M., Jawaid, M., Ishak, M. R., \& Sahari, J. (2017) Characteristics of Eucheuma cottonii waste from East Malaysia: physical, thermal and chemical composition. European Journal of Phycology, 52(2), 200-207.

Karbowiak, T., Debeaufort, F., \& Voilley, A. (2007) Influence of thermal process on structure and functional properties of emulsion-based edible films. Food Hydrocolloids, 21(5-6), 879-888.

Lacroix, M., \& Le Tien, C. (2005) Edible films and coatings from nonstarch polysaccharides. In Innovations in food packaging (pp. 338-361). Academic Press.

Lahaye, M., \& Kaeffer, B. (1997) Seaweed dietary fibres: structure, physic-chemical and biological properties relevant to intestinal physiology. Science des Aliments (France).

Larotonda, F. D. S. (2007) Biodegradable films and coatings obtained from carrageenan from Mastocarpus stellatus and starch from Quercus suber.

Laufer, G., Kirkland, C., Cain, A. A., \& Grunlan, J. C. (2013) Oxygen barrier of multilayer thin films comprised of polysaccharides and clay. Carbohydrate Polymers, 95(1), 299-302.

Lee, R. E. (2008) Phycology. Cambridge University Press.

Li, D., Li, L., Luo, Z., Lu, H., \& Yue, Y. (2017) Effect of nano-ZnO-packaging on chilling tolerance and pectin metabolism of peaches during cold storage. Scientia Horticulturae, 225, 128-133.

Mahajan, P. V., Caleb, O. J., Singh, Z., Watkins, C. B., \& Geyer, M. (2014) Postharvest treatments of fresh produce. Philosophical Transactions of the Royal Society A: Mathematical, Physical and Engineering Sciences, 372(2017), 20130309.

Masarin, F., Cedeno, F. R. P., Chavez, E. G. S., De Oliveira, L. E., Gelli, V. C., \& Monti, R. (2016) Chemical analysis and biorefinery of red algae Kappaphycus alvarezii for efficient production of glucose from residue of carrageenan extraction process. Biotechnology for Biofuels, 9(1), 122.

Mohamed, S.A., El-Sakhawy, M., \& El-Sakhawy, M. A. M. (2020) Polysaccharides, protein and lipid-based natural edible films in food packaging: a review. Carbohydrate Polymers, 116178.

Mustapha, S., Chandar, H., Abidin, Z. Z., Saghravani, R., \& Harun, M. Y. (2011) Production of semi-refined carrageenan from Eucheuma cotonii.

Mbele, N. P. (2017) Evaluation of fruit growth and development over a very extended harvesting period of' Hass', 'Fuerte', 'Gem'and 'Ryan'avocado fruit (Doctoral dissertation).

Nauyoma, L. T. (2015) Environmental factors associated with Juttadinteria albata (L. Bolus) L. Bolus, population structure and assessment of its performance in trial planting at Sendelingsdrift mine (Doctoral dissertation).

Ochoa-Reyes, E., Martínez-Vazquez, G., Saucedo-Pompa, S., Montañez, J., RojasMolina, R., Leon-Zapata, M. A. D., \& 
Aguilar, C. N. (2019) Improvement of shelf life quality of green bell peppers using edible coating formulations. Journal of Microbiology, Biotechnology and Food Sciences, 2019, 2448-2451.

Oms-Oliu, G., Soliva-Fortuny, R., \& MartínBelloso, O. (2008). Using polysaccharidebased edible coatings to enhance quality and antioxidant properties of fresh-cut melon. LWT-Food Science and Technology, 41(10), 1862-1870.

Ortiz-Tafoya, M. C., Rolland-Sabaté, A., Garnier, C., Valadez-García, J., \& Tecante, A. (2018) Thermal, conformational and rheological properties of $\kappa$-carrageenansodium stearoyl lactylate gels and solutions. Carbohydrate Polymers, 193, 289-297.

Pascall, M.A., \& Lin, S. J. (2013) The application of edible polymeric films and coatings in the food industry. Food Processing \& Technology.

Pavlath, A. E., \& Orts, W. (2009) Edible films and coatings: why, what, and how? In Edible films and coatings for food applications (pp. 1-23). Springer, New York, NY.

Pereira, L. (2017) Vibrational Spectroscopy of Seaweed Polysaccharides. In Seaweed Polysaccharides (pp. 83-100). Elsevier.

Quattara, B., Simard, R. E., Piette, G., Begin, A., $\&$ Holley, R. A. (2000) Inhibition of surface spoilage bacteria in processed meats by application of antimicrobial films prepared with chitosan. International Journal of Food Microbiology, 62,139-148.

Raghav, P. K., Agarwal, N., \& Saini, M. (2016) Edible coating of fruits and vegetables: a review. International Journal of Scientific Research and Modern Education (IJSRME) Volume I (1).

Ramani, S., \& Aswini, M. (2020) Effect of seaweed coating on quality characteristics and shelf life of tomato (Lycopersicon esculentum mill). Food Science and Human Wellness.
Renn, D. (1997) Biotechnology and the red seaweed polysaccharide industry: status, needs and prospects. Trends in Biotechnology, 15(1), 9-14.

Rudolph, B. (1986) Seaweed ProductsEconomic Importance of Red Algae in The Marine and Freshwater Natural Products (Flick, GG. and Martin, RE, Eds), Chapter 22B.

Sade, A., Ali,I., \& Ariff, M.R.M. (2006) The seaweed industry in Sabah, East Malaysia. Jati Journal of Southeast Asian Studies, 11, 97-107.

Samarakoon, K., \& Jeon, Y. J. (2012) Biofunctionalities of proteins derived from marine algae-A review. Food Research International, 48(2), 948-960.

Seol, K. H., Lim, D. G., Jang, A., Jo, C., \& Lee, M. (2009) Antimicrobial effect of $\kappa$-carrageenan-based edible film containing ovotransferrin in fresh chicken breast stored at 5 C. Meat Science, 83(3), 479-483.

Siah, W. M., Aminah, A., \& Ishak, A. (2015) Edible films from seaweed (Kappaphycus alvarezii). International Food Research Journal, 22(6), 2230.

Soares, F., Chopin, T., \& Pereira, L. (2016) Review of the chemotaxonomic significance of some phycocolloids present in economically important algae (Gigartinales, Rhodophyta). Chapter, 8, 160-188.

Sung, S. Y., Sin, L. T., Tee, T. T., Bee, S. T., Rahmat, A. R., Rahman, W. A. W. A., \& Vikhraman, M. (2013) Antimicrobial agents for food packaging applications. Trends in Food Science \& Technology, 33(2), 110123.

Tan, J., Lim, P.E. and Phang, S.M. (2011) Phylogenetic relationships of Kappaphycus and Euchema in Malaysia. Seminar Rumpai Laut Kebangsaan 2011, Tawau, Sabah.

Tavassoli-Kafrani, E., Shekarchizadeh, H., \& Masoudpour-Behabadi, M. (2016) 
Development of edible films and coatings from alginates and carrageenans. Carbohydrate Polymers, 137, 360-374

Thakur, V. K., Thakur, M. K., \& Kessler, M. R. (Eds.). (2017) Handbook of Composites from Renewable Materials, Nanocomposites: Science and Fundamentals (Vol. 7). John Wiley \& Sons.

Tobacman, J. K. (2001) Review of harmful gastrointestinal effects of carrageenan in animal experiments. Environmental Health Perspectives, 109(10), 983-994.

Urbano, M.G., \& Goñi, I. (2002) Bioavailability of nutrients in rats fed on edible seaweeds, Nori (Porphyra tenera) and Wakame (Undaria pinnatifida), as a source of dietary fibre. Food Chemisry, 76(3), 281-286.

Usov, A.I. (1992) Sulfated polysaccharides of the red seaweeds. Food Hydrocolloids, 6(1), 9-23.
Vargas, M., Pastor, C., Chiralt, A., McClements, D. J., \& Gonzalez-Martinez, C. (2008) Recent advances in edible coatings for fresh and minimally processed fruits. Critical Reviews in Food Science and Nutrition, 48(6), 496-511.

Yousuf, B., Qadri, O. S., \& Srivastava, A. K. (2018) Recent developments in shelf-life extension of fresh-cut fruits and vegetables by application of different edible coatings: A review. LWT-Food Science and Technology, 89, 198-209.

Yu,S., Blennow, a., Bojko, M., Madsen, F., Olsen,C.E., \& Engelsen, S.B. (2002) Physico-chemical characterization of floridean starch of red algae. Starch-Stärke, 54(2), 66-74.

Yun, E. J., Lee, S., Kim, H. T., Pelton, J. G., Kim, S., Ko, H. J., \& Kim, K. H. (2015) The novel catabolic pathway of 3,6-anhydroL-galactose, the main component of red macroalgae, in a marine bacterium. Environmental Microbiology, 17(5), 16771688. 